Supporting information for:

\title{
Enantioselective Hydrogenation of 3-Alkylidenelactams: High- Throughput Screening Provides a Surprising Solution.
}

\author{
Tai-Yuen Yue and William A. Nugent \\ Bristol-Myers Squibb Company, Process Research and Development Department, Chambers Works, \\ P. O. Box 269, Deepwater, NJ 08023-0269 \\ william.nugent@bms.com
}

Materials and Methods. Lactam and aldehyde starting materials were purchased from Aldrich Chemical Co. (S,S)-BDPP was purchased from Strem Chemical Company, Newburyport, MA and was used as received or from Digital Specialty Chemicals, Ltd., Mississauga, Ontario, Canada in which case it was recrystallized from isopropanol prior to use. Bis(cyclooctadiene)iridium(I) tetrafluoroborate was purchased from Strem Chemical Company, Newburyport, MA or from Colonial Metals, Inc., Elkton, MD and was used as received. Chiral HPLC analytical methods were developed using racemic samples prepared by hydrogenation of the corresponding substrates over a 5\% palladium on carbon catalyst. The Chiralpak AD, Chiralpak AS, and Chiralpak OD columns used to determine enantiomeric purity of the products were purchased from Chiral Technologies, Inc., Exton, PA. NMR spectra were obtained at $25^{\circ} \mathrm{C}$ in $\mathrm{CDCl}_{3}$ except as indicated and field strengths for the various nuclei were as follows: ${ }^{1} \mathrm{H}(400.1 \mathrm{MHz})$, ${ }^{13} \mathrm{C}(100.6 \mathrm{MHz}),{ }^{19} \mathrm{~F}(376.5 \mathrm{MHz}),{ }^{31} \mathrm{P}$ ( $\left.162.0 \mathrm{MHz}\right)$. Coupling constants $(J)$ are given in Hertz. Flash chromatography was performed on 220-400 mesh silica (E. Merck) following the standard procedure [Still, W. C.; Kahn, M.; Mitra, A. J. Org. Chem. 1978, 43, 2923].

\section{Synthesis of 3-(Alkylidene)lactam Substrates.}

General Procedure: 3-(4-Fluorobenzylidene)valerolactam. Valerolactam (20.0g, $202 \mathrm{mmol})$ was dissolved in toluene $(80 \mathrm{ml})$. To this solution, trifluoroacetic anhydride (TFAA) $(46.7 \mathrm{~g}, 222 \mathrm{mmol})$ was charged slowly at $5{ }^{\circ} \mathrm{C}$. Upon complete addition, the solution was held at $25{ }^{\circ} \mathrm{C}$ for $30 \mathrm{~min}$. Toluene was removed under vacuum using a rotary evaporator. Toluene $(50 \mathrm{ml})$ was added to the concentrate and again removed under vacuum, and this process was repeated twice. The resulting liquid (TFA-protected lactam) was mixed with 4-fluorobenzaldehyde $(22.6 \mathrm{~g}, 182 \mathrm{mmol})$ and the mixture was slowly charged to a $1 \mathrm{M}$ solution of potassium t-butoxide in THF $(240 \mathrm{ml}, 240 \mathrm{mmol})$ at $5{ }^{\circ} \mathrm{C}$. Upon complete addition, the mixture was heated to $55^{\circ} \mathrm{C}$ and held for $1 \mathrm{~h}$. The reaction mixture was concentrated to a thick slurry under vacuum using a rotary evaporator. To the concentrate, water $(300 \mathrm{ml})$ was added to precipitate the crude product. The slurry was cooled to $5{ }^{\circ} \mathrm{C}$ and held for $1 \mathrm{~h}$. Solid was filtered, washed with water, and dried in vacuum oven overnight. The crude product was purified by re-slurry in $20 \%$ isopropyl acetate in heptane 
(100 ml) at $65{ }^{\circ} \mathrm{C}$ for $1 \mathrm{~h}$. The slurry was cooled to $25^{\circ} \mathrm{C}$ and held for $2 \mathrm{~h}$. Solid was filtered, washed with $20 \%$ isopropyl acetate in heptane $(3 \times 30 \mathrm{ml})$. Purified product was dried in vacuum oven. Yield of dried product was $24.8 \mathrm{~g}(66 \%) .{ }^{1} \mathrm{H}$ NMR $\delta 1.88(\mathrm{~m}, 2 \mathrm{H}), 2.80(\mathrm{~m}, 2 \mathrm{H}), 3.45(\mathrm{~m}, 2 \mathrm{H}), 7.08(\mathrm{~m}, 3 \mathrm{H}), 7.40(\mathrm{~m}$, 2H), 7.77 (s, 1H). ${ }^{13} \mathrm{C}$ NMR $\delta$ 23.16, 26.37, 42.17, 115.58 (d, $J=21.4, \mathrm{C}-3$ ') 129.47 (C-3), 131.82 (d, $J=$ 8.2, C-2'), 132.08 (d, $J=3.6$, C-1'), 134.65 (olefinic), 162.53 (d, $J=249$, C-4'), 166.99 (C-2). ${ }^{19}$ F NMR: $\delta$ -113.15 .

3-(4-Trifluoromethylbenzylidene)valerolactam. ${ }^{1} \mathrm{H}$ NMR $\left(\right.$ DMSO- $\left._{6}\right) \delta 1.71(\mathrm{~m}, 2 \mathrm{H}), 2.72(\mathrm{~m}$, 2H), $3.27(\mathrm{~m}, 2 \mathrm{H}), 7.62(\mathrm{~m}, 3 \mathrm{H}), 7.78(\mathrm{~m}, 2 \mathrm{H}), 7.93(\mathrm{~s}, 1 \mathrm{H}) .{ }^{19} \mathrm{~F}$ NMR (DMSO-d 6 ): $\delta-61.53$.

3-(4-Methoxylbenzylidene)valerolactam. ${ }^{1} \mathrm{H}$ NMR $\delta 1.89$ (m, 2H), $2.82(\mathrm{~m}, 2 \mathrm{H}), 3.43$ (m, 2H), $3.83(\mathrm{~s}, 3 \mathrm{H}), 6.82(\mathrm{br}, 1 \mathrm{H}), 6.92(\mathrm{~d}, J=9.0,2 \mathrm{H}), 7.38(\mathrm{~d}, J=9.0,2 \mathrm{H}), 7.78(\mathrm{~s}, 1 \mathrm{H}) .{ }^{13} \mathrm{C}$ NMR $\delta 23.25$, 26.53, 42.17, 55.50, 113.98 (C-3'), 127.60, 128.61, 131.74 (C-2'), 135.50 (olefin), 159.69 (C-4'), 167.36 (C-2).

3-(2-Furanylmethylidene)valerolactam. ${ }^{1} \mathrm{H}$ NMR $\delta 1.93(\mathrm{~m}, 2 \mathrm{H}), 2.96(\mathrm{~m}, 2 \mathrm{H}), 3.42(\mathrm{~m}, 2 \mathrm{H})$, $6.50(\mathrm{~s}, 1 \mathrm{H}), 6.58(2,1 \mathrm{H}), 6.88(\mathrm{br}, 1 \mathrm{H}), 7.54(\mathrm{~m}, 2 \mathrm{H})$.

3-(3-Furanylmethylidene)valerolactam. ${ }^{1} \mathrm{H}$ NMR: $\delta 1.91(\mathrm{~m}, 2 \mathrm{H}), 2.82(\mathrm{~m}, 2 \mathrm{H}), 3.37(\mathrm{~m}, 2 \mathrm{H})$, 6.58 (s, 1H), 7.40 (br, 1H), 7.48 (s, 1H). ${ }^{13} \mathrm{C}$ NMR: $\delta 22.71,26.51,41.80,111.15,122.01,126.73,127.49$, 143.56, 144.14, 167.20.

3-(Butylidene)valerolactam. ${ }^{1} \mathrm{H}$ NMR: $\delta 0.93(\mathrm{~m}, 3 \mathrm{H}), 1.48(\mathrm{~m}, 2 \mathrm{H}), 1.82(\mathrm{~m}, 2 \mathrm{H}), 2.10(\mathrm{~m}$, 2H), $2.48(\mathrm{~m}, 2 \mathrm{H}), 3.35(\mathrm{~m}, 2 \mathrm{H}), 6.84(\mathrm{~m}, 1 \mathrm{H})$.

3-(Isobutylidene)valerolactam. ${ }^{1} \mathrm{H}$ NMR: $\delta 1.02(\mathrm{~d}, \mathrm{~J}=8.0,6 \mathrm{H}), 1.83(\mathrm{~m}, 2 \mathrm{H}), 2.49(\mathrm{~m}, 2 \mathrm{H})$, $2.60(\mathrm{~m}, 1 \mathrm{H}), 3.35(\mathrm{~m}, 2 \mathrm{H}), 6.68(\mathrm{~d}, J=12.8,1 \mathrm{H}), 7.05(\mathrm{br}, 1 \mathrm{H}) .{ }^{13} \mathrm{C}$ NMR: $\delta 22.18,23.00,24.47,27.17$, $42.12,126.53,145.65,167.42$.

3-(4-Fluorobenzylidene)-2-pyrrolidinone. ${ }^{1} \mathrm{H}$ NMR (DMSO- $\mathrm{d}_{6}$ ): $\delta 3.00$ (br m, $2 \mathrm{H}$ ), 3.38 (m, 2 H), 7.09 (s, $1 \mathrm{H}), 7.28(\mathrm{~m}, 2 \mathrm{H}), 7.60(\mathrm{~m}, 2 \mathrm{H}), 8.18$ (br s, 1H). ${ }^{13} \mathrm{C}$ NMR (DMSO-d $)$ ): $\delta 25.96,39.04$, $116.02(\mathrm{~d}, J=21), 126.94,131.76,132.60,162.08(\mathrm{~d}, J=246), 170.81 .{ }^{19} \mathrm{~F}$ NMR (DMSO-d 6 ): $\delta-113.09$.

3-(Butylidene)-2-pyrrolidinone. ${ }^{1} \mathrm{H}$ NMR: $\delta 0.90(\mathrm{t}, J=7), 1.48(\mathrm{~m}, 2 \mathrm{H}), 2.10(\mathrm{~m}, 2 \mathrm{H}), 2.71(\mathrm{~m}$, $2 \mathrm{H}), 3.44$ (m, 2H), 6.41 (m, 1H), 7.87 (br s, 1H). ${ }^{13} \mathrm{C}$ NMR: $\delta 14.01,21.95,23.98,31.59,39.71,131.33$, 133.17, 172.59 .

3-(4-Fluorobenzylidene)caprolactam. ${ }^{1} \mathrm{H}$ NMR: $\delta 1.81(\mathrm{~m}, 2 \mathrm{H}), 1.92(\mathrm{~m}, 2 \mathrm{H}), 2.60(\mathrm{~m}, 2 \mathrm{H})$, $3.21(\mathrm{~m}, 2 \mathrm{H}), 6.50(\mathrm{br}, 1 \mathrm{H}), 7.08(\mathrm{~m}, 2 \mathrm{H}), 7.14(\mathrm{~s}, 1 \mathrm{H}), 7.38(\mathrm{~m}, 2 \mathrm{H}) .{ }^{13} \mathrm{C}$ NMR: $\delta$ 27.46, 27.50, 28.79, 42.28, 115.61 (d, $J=21.4$, C-3'), 131.09, (d, $J=8.1$, C-2'), 132.13 (d, $J=3.4$, C-1'), 133.52 (olefin), 137.97 (C-3), 162.39, (d, $\left.J=248.3, \mathrm{C}-4{ }^{\prime}\right), 176.17(\mathrm{C}-2) .{ }^{19} \mathrm{~F}$ NMR: $\delta$-113.82.

1-Methyl-3-(4-fluorobenzylidene)valerolactam. ${ }^{1} \mathrm{H}$ NMR: $\delta 1.89$ (m, 2H), 2.77 (m, 2H), 3.10 (s, 3H), 3.42 (m, 2H), 7.08 ( m, 2H), 7.32 ( m, 2H), 7.78 ( s, 1H). ${ }^{13} \mathrm{C}$ NMR: $\delta 23.05,26.48,36.01,49.93$, 115.47 (d, $J=21.5$, C-3'), 130.04 (C-3), 131.60 (d, $J=8.1$, C-2'), 132.51 (d, $J=3.2$, C-1'), 133.85 (olefinic), 162.37 (d, $J=245.4, \mathrm{C}-4$ '), 165.25 (C-2). 


\section{Hydrogenation Studies}

Preparation of $[(S, S)-(\mathbf{B D P P}) \operatorname{Ir}(\mathbf{C O D})] \mathbf{B F}_{4}$. In a nitrogen-filled glove box, $(S, S)-2,4-$

bis(diphenylphosphino)pentane $(4.40 \mathrm{~g}, 100 \mathrm{mmol})$ and bis(1,5-cyclooctadiene)iridium(I) tetrafluoroborate (4.90 g, ca. $91 \%$ purity, $91 \mathrm{mmol})$ were dissolved in dichloromethane $(50 \mathrm{~mL})$. Diethyl ether $(100 \mathrm{~mL})$ was added dropwise to the stirred solution. The resultant precipitate was collected by filtration to afford $[(\mathrm{S}, \mathrm{S})-(\mathrm{BDPP}) \operatorname{Ir}(\mathrm{COD})] \mathrm{BF}_{4}(6.15 \mathrm{~g}, 82 \%)$ as a red-violet microcrystalline solid. The ${ }^{31} \mathrm{P} \mathrm{NMR}$ spectrum was particularly helpful in ascertaining catalyst purity; the purified complex exhibited a singlet at $\delta 16.7$ ppm and was free of unreacted BDPP as indicated by the absence of a resonance at $\delta 0.5 \mathrm{ppm}$. ${ }^{1} \mathrm{H}$ NMR: $\delta$ $1.02(\mathrm{t}, J=7,3 \mathrm{H}), 1.04(\mathrm{t}, J=7,3 \mathrm{H}) 1.52-1.95(\mathrm{~m}, 6 \mathrm{H}), 2.48(\mathrm{~m}, 4 \mathrm{H}), 2.91(\mathrm{~m}, 2 \mathrm{H}), 3.52(\mathrm{~m}, 2 \mathrm{H}$, vinyl), 4.33 (m, 2H, vinyl), 7.25 (m, 4H), 7.40-7.57 (m, 6H), 7.74 (m, 6H), 8.13 (m, 4H).

General Procedure: $(S)-3$-p-fluorobenzyl-2-piperidone. In a nitrogen-filled glove box, a Fisher-Porter tube was charged with [(S,S)-(BDPP) $\operatorname{Ir}\left(\mathrm{COD}_{\mathrm{B}} \mathrm{BF}_{4}(20 \mathrm{mg}, 0.024 \mathrm{mmol})\right.$ and 3-(pfluorobenzylidene)-2-piperidone (1.00 g, $4.9 \mathrm{mmol})$. Methanol $(5 \mathrm{~mL})$ and dichloromethane $(5 \mathrm{~mL})$ were added and the system was flushed 4 times with hydrogen and pressured to $65 \mathrm{psi}_{2}$. After $24 \mathrm{~h}$ the reaction mixture was filtered through a short pad of silica. The solvent was removed at reduced pressure to afford (S)-3-p-fluorobenzyl-2-piperidone $(0.97 \mathrm{~g}, 97 \%)$ as a white crystalline solid. Chiral HPLC analysis (Chiralpak AS, $60 \%$ heptane, 39.2\% isopropanol, $0.4 \%$ trifluoroacetic acid, $0.4 \%$ n-hexylamine, $40{ }^{\circ} \mathrm{C}$ ) indicated that conversion was $100 \%$ and the enantiomeric excess was $91 \% .{ }^{19} \mathrm{~F}$ NMR: $\delta-117.63 ;{ }^{13} \mathrm{C}$ NMR: $\delta$ 20.18, 24.33, 35.56, 41.27, 41.76, 114.06 (d, $J=21 \mathrm{~Hz}), 129.61,134.44,160.42$ (d, $J=241 \mathrm{~Hz})$, 173.49; ${ }^{1} \mathrm{H}$ NMR: $\delta 1.43(\mathrm{~m}, 1 \mathrm{H}), 1.57-1.89(\mathrm{~m}, 3 \mathrm{H}), 2.50(\mathrm{~m}, 1 \mathrm{H}), 2.71$ (app dd, $\left.1 \mathrm{H}\right), 3.29(\mathrm{~m}, 3 \mathrm{H}), 6.01$ (br s, 1H), $6.98(\mathrm{~m}, 2 \mathrm{H}), 7.16(\mathrm{~m}, \mathrm{H})$.

3-p-Trifluoromethylbenzyl-2-piperidone. White crystalline solid (96\%). Chiral HPLC analysis (Chiralpak AS, $60 \%$ heptane, 39.2\% isopropanol, $0.4 \%$ trifluoroacetic acid, $0.4 \%$ n-hexylamine, $40{ }^{\circ} \mathrm{C}$ ) indicated that conversion was $100 \%$ and the enantiomeric excess was $87 \%$. ${ }^{19} \mathrm{~F} \mathrm{NMR}$ : $\delta-62.78 ;{ }^{13} \mathrm{C}$ NMR $\delta 21.50,25.70,37.40,42.50,42.79,124.26$ (q, $J=224), 125.46,128.67(\mathrm{q}, J=32), 144.32,174.25 ;{ }^{1} \mathrm{H}$ NMR: $\delta 1.42(\mathrm{~m}, 1 \mathrm{H}), 1.60-1.89(\mathrm{~m}, 3 \mathrm{H}), 2.58(\mathrm{~m}, 1 \mathrm{H}), 2.79(\mathrm{app} \mathrm{dd}, 1 \mathrm{H}), 3.31(\mathrm{~m}, 2 \mathrm{H}), 3.43(\mathrm{app} \mathrm{dd}$, $1 \mathrm{H}), 7.10$ (br s, 1H), 7.34 (d, $J=8,2 \mathrm{H}), 7.53(\mathrm{~d}, J=8,2 \mathrm{H})$.

3-p-Methoxybenzyl-2-piperidone. White crystalline solid (92\%). Chiral HPLC analysis (Chiralpak AS, $60 \%$ heptane, 39.2\% isopropanol, $0.4 \%$ trifluoroacetic acid, $0.4 \%$ n-hexylamine, $40{ }^{\circ} \mathrm{C}$ ) indicated that conversion was $100 \%$ and the enantiomeric excess was $90 \% .{ }^{13} \mathrm{C}$ NMR: $\delta 21.32,25.49$, 36.72, 42.56, 43.11, 55.40, 113.93, 130.37, 131.99, 158.18, 174.93; ${ }^{1} \mathrm{H}$ NMR: $\delta 1.44(\mathrm{~m}, 1 \mathrm{H}), 1.62(\mathrm{~m}$, $1 \mathrm{H}), 1.68-1.75(\mathrm{~m}, 2 \mathrm{H}), 2.50(\mathrm{~m}, 1 \mathrm{H}), 2.64(\mathrm{app} \mathrm{dd}, 1 \mathrm{H}), 3.20-3.37$ (m, 3H), 3.79 (s, 3H), 6.82 (d, J = 9, 2H), 7.09 (br s, 1H), $7.12(\mathrm{~d}, J=9,2 \mathrm{H})$.

3-(2-Furanylmethyl)-2-piperidone. White crystalline solid (100\%). Chiral HPLC analysis (Chiralpak AD, 85\% heptane, $15 \%$ ethanol, $30^{\circ} \mathrm{C}$ ) indicated that conversion was $100 \%$ and the 
enantiomeric excess was 95\%. ${ }^{13} \mathrm{C}$ NMR: $\delta$ 21.55, 26.12, 29.99, 40.91, 42.57, 106.80, 110.39, 141.38, 153.99, 174.20; ${ }^{1} \mathrm{H}$ NMR: $\delta 1.49$ (m, $\left.1 \mathrm{H}\right), 1.68$ (m, $\left.1 \mathrm{H}\right), 1.75-1.91$ (m, $\left.2 \mathrm{H}\right), 2.62(\mathrm{~m}, 1 \mathrm{H}), 2.82(\mathrm{~m}, 1 \mathrm{H})$, 3.29 (m, $3 \mathrm{H}), 6.06$ (m, $1 \mathrm{H}), 6.29$ (m, $1 \mathrm{H}), 7.29$ (m, $1 \mathrm{H}), 7.34$ (br s, $1 \mathrm{H})$.

3-(3-Furanylmethyl)-2-piperidone. White crystalline solid (98\%). Chiral HPLC analysis (Chiralpak AS, $60 \%$ heptane, 39.2\% isopropanol, $0.4 \%$ trifluoroacetic acid, $0.4 \%$ n-hexylamine, $40{ }^{\circ} \mathrm{C}$ ) indicated that conversion was $100 \%$ and the enantiomeric excess was $95 \%$. ${ }^{1} \mathrm{H}$ NMR: $\delta 1.49(\mathrm{~m}, 1 \mathrm{H}), 1.69$ (m, 1H), $1.86(\mathrm{~m}, 2 \mathrm{H}), 2.47(\mathrm{~m}, 1 \mathrm{H}), 2.71(\mathrm{~m}, 1 \mathrm{H}), 2.99(\mathrm{~m}, 1 \mathrm{H}), 3.28(\mathrm{~m}, 2 \mathrm{H}), 6.29(\mathrm{~s}, 1 \mathrm{H}), 7.04(\mathrm{br} \mathrm{s}$, $1 \mathrm{H}), 7.24(\mathrm{~s}, 1 \mathrm{H}), 7.32(\mathrm{~s}, 1 \mathrm{H}) .{ }^{13} \mathrm{C}$ NMR: $\delta 21.49,25.66,26.58,41.68,42.52,111.60,122.34,140.28$, $142.98,174.80$.

3-Butyl-2-piperidone. White crystalline solid (93\%). Chiral gas chromatographic analysis (Restek GammaDex-SA column, $130{ }^{\circ} \mathrm{C}$ for $5 \mathrm{~min}$, then programmed to $200{ }^{\circ} \mathrm{C}$ at $10 \% \mathrm{~min}$ ) indicated that conversion was $95 \%$ and the enantiomeric excess was $90 \%$. ${ }^{13} \mathrm{C}$ NMR: $\delta 14.24,21.27,22.85,26.04,29.25$, 31.36, 40.96, 42.38, 176.02; ${ }^{1} \mathrm{H}$ NMR: $\delta 0.91(\mathrm{t}, J=7,3 \mathrm{H}), 1.22-1.58(\mathrm{~m}, 6 \mathrm{H}), 1.70(\mathrm{~m}, 1 \mathrm{H}), 1.79-2.00$ (m, 3H), $2.24(\mathrm{~m}, 1 \mathrm{H}), 3.29(\mathrm{~m}, 2 \mathrm{H}), 7.25(\mathrm{br} \mathrm{s}, 1 \mathrm{H})$.

3-Isobutyl-2-piperidone. White crystalline solid (100\%). Chiral HPLC analysis (Chiralpak AS, $60 \%$ heptane, $39.2 \%$ isopropanol, $0.4 \%$ trifluoroacetic acid, $0.4 \%$ n-hexylamine, $40{ }^{\circ} \mathrm{C}$ ) indicated that conversion was $100 \%$ and the enantiomeric excess was $81 \% .{ }^{1} \mathrm{H}$ NMR: $\delta 0.88(\mathrm{~d}, 3 \mathrm{H}), 0.95(\mathrm{~d}, 3 \mathrm{H}), 1.35$ $(\mathrm{m}, 1 \mathrm{H}), 1.49(\mathrm{~m}, 1 \mathrm{H}), 1.71(\mathrm{~m}, 2 \mathrm{H}), 1.82(\mathrm{~m}, 2 \mathrm{H}), 1.96(\mathrm{~m}, 1 \mathrm{H}), 3.31(\mathrm{~m}, 2 \mathrm{H}), 6.80(\mathrm{br} \mathrm{s}, 1 \mathrm{H}) .{ }^{13} \mathrm{C} \mathrm{NMR}$ : $\delta 21.16,21.29,23.82,25.13,6.24,39.01,40.72,42.48,176.12$.

3-p-Fluorobenzyl-2-pyrrolidinone. White crystalline solid (100\%). Chiral HPLC analysis (Chiralpak OD, 95\% heptane, $4.9 \%$ isopropanol, $0.05 \%$ trifluoroacetic acid, $0.05 \%$ n-hexylamine, $40{ }^{\circ} \mathrm{C}$ ) indicated that conversion was $100 \%$ and the enantiomeric excess was $89 \% .{ }^{19} \mathrm{~F}$ NMR $\delta-117.39 ;{ }^{13} \mathrm{C}$ NMR $\delta 26.92,35.90,40.44,42.88,115.44(\mathrm{~d}, J=21), 130.58,135.21,161.77(\mathrm{~d}, J=241), 179.72 ;{ }^{1} \mathrm{H}$ NMR: $\delta$ $1.83(\mathrm{~m}, 1 \mathrm{H}), 2.15(\mathrm{~m}, 1 \mathrm{H}), 2.66(\mathrm{~m}, 2 \mathrm{H}), 3.11-3.32(\mathrm{~m} .3 \mathrm{H}), 6.47$ (br s, 1H), $7.00(\mathrm{~m}, 2 \mathrm{H}), 7.15(\mathrm{~m}, 2 \mathrm{H})$.

3-Butyl-2-pyrrolidinone. White crystalline solid (98\%). Chiral HPLC analysis (Chiralcel AS$\mathrm{RH}$, solvent $\mathrm{A}=0.05 \%$ trifluoroacetic acid in $20: 80 \mathrm{MeOH} /$ water, solvent $\mathrm{B}=0.05 \%$ trifluoroacetic acid in 20:80 MeOH/acetonitrile) indicated 82\% ee. ${ }^{1} \mathrm{H}$ NMR: $\delta 0.91(\mathrm{t}, J=6.8,3 \mathrm{H}), 1.36(\mathrm{~m}, 5 \mathrm{H}), 1.75$ (ddd, $J=3.6,8.5,11.8,1 \mathrm{H}), 1.82-1.91(\mathrm{~m}, 1 \mathrm{H}), 2.21-2.39(\mathrm{~m}, 2 \mathrm{H}), 3.23-3.39(\mathrm{~m}, 2 \mathrm{H}), 7.32(\mathrm{~s}, 1 \mathrm{H}),{ }^{13} \mathrm{C} \mathrm{NMR}: \delta$ $14.16,22.82,27.64,29.68,30.73,40.73,41.26,181.44$.

3-(p-Fluorobenzyl)caprolactam. White crystalline solid (92\%). Chiral HPLC analysis (Chiralpak AS, $60 \%$ heptane, 39.2\% isopropanol, $0.4 \%$ trifluoroacetic acid, $0.4 \%$ n-hexylamine, $40{ }^{\circ} \mathrm{C}$ ) indicated that conversion was $100 \%$ and the enantiomeric excess was $75 \% .{ }^{19} \mathrm{~F}$ NMR: $\delta-117.99 ;{ }^{13} \mathrm{C}$ NMR: $\delta$ 28.93, 29.47, 29.94, 36.73, 42.28, 45.65, 115.18 (d, $J=21), 130.81,136.47,161.49$ (d, $J=241$ ), 179.79; ${ }^{1} \mathrm{H}$ NMR: $\delta 1.43(\mathrm{~m}, 3 \mathrm{H}), 1.70(\mathrm{~m}, 1 \mathrm{H}), 1.76(\mathrm{~m}, 1 \mathrm{H}), 1.91(\mathrm{~m}, 1 \mathrm{H}), 2.54(\operatorname{app~dd}, 1 \mathrm{H}), 2.67(\mathrm{~m}$, $1 \mathrm{H}), 3.12-3.31(\mathrm{~m}, 3 \mathrm{H}), 6.78(\mathrm{br} \mathrm{s}, 1 \mathrm{H}), 6.96(\mathrm{~m}, 2 \mathrm{H}), 7.14(\mathrm{~m}, 2 \mathrm{H})$. 
1-Methyl-3-(p-fluorobenzyl)-2-piperidone. White crystalline solid (97\%).. HPLC analysis (Chiralpak $\mathrm{AD}, 95 \%$ heptane, $5 \%$ ethanol, $20^{\circ} \mathrm{C}$ ) indicated that conversion was $100 \%$ and the enantiomeric excess was 67\%. ${ }^{1} \mathrm{H}$ NMR: $\delta 1.43(\mathrm{~m}, 1 \mathrm{H}), 1.70(\mathrm{br} \mathrm{m}, 2 \mathrm{H}), 1.82(\mathrm{br} \mathrm{m}, 1 \mathrm{H}), 2.50(\mathrm{br} \mathrm{m}, 1 \mathrm{H}), 2.67$ (app t, 1H), 2.93 (s, 3H), 3.25 (br m, 2H), 3.36 (app d, 1H), 6.92 (m, H), 7.15 (m, 2H). ${ }^{13} \mathrm{C}$ NMR: $\delta 21.54,25.81$, 34.98, 37.03, 43.40, 50.16, 115.08 (d, $J=21), 130.72,135.92,161.45$ (d, $J=242), 171.76$.

\section{$\underline{\text { Operation at Multi-Kilogram Scale }}$}

Substrate Synthesis. A 30 gallon (120 L) glass-lined reactor was charged with valerolactam $(18.0 \mathrm{~kg})$ and toluene $(42.0 \mathrm{~kg})$. Trifluoroacetic anhydride $(42.0 \mathrm{~kg})$ was added over $30 \mathrm{~min}$ and the mixture was stirred for an additional $60 \mathrm{~min}$. Volatiles were distilled off at $60-70{ }^{\circ} \mathrm{C}$ at 140 torr. Toluene $(50.0 \mathrm{~kg}$ ) was added and the mixture was further distilled until approximately $27 \mathrm{~L}$ remained in the pot and this process was repeated twice. To the residue was added tert-butanol $(18.8 \mathrm{~kg})$ and 4-fluorobenzaldehyde $(20.3 \mathrm{~kg})$. The resultant solution was slowly transferred to 100 gallon $(400 \mathrm{~L})$ glass-lined reactor containing potassium tert-butoxide in tetrahydrofuran (122 kg of a $20 \%$ solution). The mixture was warmed to $60{ }^{\circ} \mathrm{C}$ for $1 \mathrm{~h}$. Volatiles were distilled at $40-50{ }^{\circ} \mathrm{C}$ at 250 torr to a volume of approximately 100 L. Water $(180 \mathrm{~L})$ was added to the slurry at $40{ }^{\circ} \mathrm{C}$ and the mixture was cooled to $5{ }^{\circ} \mathrm{C}$ for $2 \mathrm{~h}$ and collected by filtration. The wet cake was washed and reslurried with water $(3 \times 200 \mathrm{~L})$ and dried in a tray dryer (50 ${ }^{\circ} \mathrm{C}$, 50 torr) to afford crude 3-p-fluorobenzylidene-2-piperidone (32.6 kg) whose purity by HPLC was 70.3 wt \% (95.4 area \%).

Purification of Substrate. The crude product was charged to a 100 gallon (400 L) glass-lined reactor with isopropyl acetate $(80 \mathrm{~kg})$. Residual water was removed by distillation at atmospheric pressure to a volume of $70 \mathrm{~L}$. Heptane $\left(56 \mathrm{~kg}\right.$ ) was added at $80^{\circ} \mathrm{C}$ and the slurry was cooled to $5{ }^{\circ} \mathrm{C}$. Filtration, washing with a mixture of isopropyl acetate $(8 \mathrm{~kg})$ and heptane $(62 \mathrm{~kg})$ at $5{ }^{\circ} \mathrm{C}$, and drying $\left(50{ }^{\circ} \mathrm{C}, 50\right.$ torr $)$ afforded purified 3-p-fluorobenzylidene-2-piperidone (20.0 kg, 54\%) which by HPLC analysis was $99.1 \mathrm{wt}$ $\%$ (99.6 area \%). In order to ensure the material was free from catalyst poisons, a portion of the product $(19.7 \mathrm{~kg})$ was further crystallized by dissolution in isopropanol $(80 \mathrm{~L})$ and water $(20 \mathrm{~L})$ at $75^{\circ} \mathrm{C}$. The mixture was seeded at $70{ }^{\circ} \mathrm{C}$ and cooled to $30^{\circ} \mathrm{C}$ whereupon water $(140 \mathrm{~L})$ was added. After standing overnight, the mixture was cooled to $2{ }^{\circ} \mathrm{C}$ and the product was collected by filtration, washed with $10 \%$ isopropanol in water $(88 \mathrm{~L})$, and dried $\left(65^{\circ} \mathrm{C}, 50\right.$ torr). This afforded crystalline 3-p-fluorobenzylidene-2piperidone ( $19.5 \mathrm{~kg}$ ) containing $0.2 \%$ residual isopropanol which was 99.7 area $\%$ by HPLC. ${ }^{19} \mathrm{~F} \mathrm{NMR:} \delta$ -112.99; ${ }^{1} \mathrm{H}$ NMR: $\delta 1.88(\mathrm{~m}, 2 \mathrm{H}), 2.80(\mathrm{~m}, 2 \mathrm{H}), 3.45(\mathrm{~m}, 2 \mathrm{H}), 7.08(\mathrm{~m}, 3 \mathrm{H}), 7.40(\mathrm{~m}, 2 \mathrm{H}), 7.77(\mathrm{~s}, 1 \mathrm{H})$;

${ }^{13}$ C NMR: $\delta 23.16,26.37,42.17,115.58$ (d, $J=21.4$, C-3'), $129.47(\mathrm{C}-3), 131.82$ (d, $J=8.2, \mathrm{C}^{2}{ }^{\prime}$ ), 132.08 (d, J = 3.6, C-1'), 134.65 (olefinic), 162.53 (d, $J=249$, C-4'), 166.99 (C-2).

Large Scale Hydrogenation. A 100 gallon (400 L) glass-lined reactor was charged with recrystallized 3-p-fluorobenzylidene-2-piperidone (19.5 kg), methanol (75 kg, 5 volumes), and dichloromethane (126 kg, 5 volumes). (2S,4S)-(-)-2,4-bis(diphenylphosphino)pentane (97 g, $0.25 \mathrm{~mol} \%$ ) 
and bis(1,5-cyclooctadiene)iridium(I) tetrafluoroborate (109 g, $0.25 \mathrm{~mol} \%)$ was added to the stirred solution under nitrogen. The reactor was pressured to $55 \mathrm{psi}(0.46 \mathrm{MPa})$ hydrogen and stirred for $13 \mathrm{~h}$ at which time no starting material remained. The solvent was replaced with toluene by successive vacuum distillation and toluene charges and the resultant solution was filtered through a bed of charcoal (Darco G60 ) and silica gel 60. The resultant solution contained (S)-3-p-fluorobenzyl-2-piperidone (19.1 kg, 97\%); NMR and chiral HPLC analysis as above indicated the enantiomeric excess was $91 \%$.

Large scale LAH reduction. A solution of (S)-3-p-fluorobenzyl-2-piperidone (6.4 kg, 30.8 moles) in $120 \mathrm{~L}$ of toluene was cooled to $10^{\circ} \mathrm{C}$. A solution of LAH-bis THF in toluene $(1.0 \mathrm{M}, 27.8 \mathrm{~kg})$ was added at a temperature below $15^{\circ} \mathrm{C}$. The batch was heated to $40{ }^{\circ} \mathrm{C}$ and stirred for $3 \mathrm{~h}$. The batch was quenched by slow addition to a Rochelle salt solution ( $16.4 \mathrm{~kg}$ in $90 \mathrm{~L}$ of water) and stirred for $15 \mathrm{~min}$. The organic phase was washed with $10 \%$ brine followed by water. The toluene solution was concentrated by vacuum distillation to a volume of about $60 \mathrm{~L}$. The resultant solution contained $(S)$-3-p-fluorobenzylpiperidine (5.0 kg, 25.9 moles, 84\%). Chiral HPLC analysis indicated enantiomeric excess was $90 \%$.

Large scale mandelic acid salt formation. A solution of (S)-3-(p-fluorobenzyl)piperidine (12.2 $\mathrm{kg}, 63.1$ moles at $90 \%$ e.e.) in $120 \mathrm{~L}$ of toluene was heated to $70{ }^{\circ} \mathrm{C}$. To this hot solution was added a hot solution (at $70{ }^{\circ} \mathrm{C}$ ) of R-(-)-mandelic acid $(10.1 \mathrm{~kg}, 66.4$ moles) in acetonitrile $(50 \mathrm{~L})$. The resulting mixture was stirred for $1 \mathrm{~h}$ at $70{ }^{\circ} \mathrm{C}$, cooled to $25^{\circ} \mathrm{C}$ over $2 \mathrm{~h}$, and then held for $2 \mathrm{~h}$. The slurry was filtered, washed with acetonitrile, and dried in vacuum dryer. Yield was $21.1 \mathrm{~kg}(96.7 \%)$. Chiral HPLC analysis indicated enantiomeric excess was $99 \%$.

\section{Details of Screening Protocol.}

The metal precursors utilized in the initial screen were $\left[\mathrm{Rh}\left(\mathrm{C}_{2} \mathrm{H}_{4}\right)_{2} \mathrm{Cl}\right]_{2},\left[\operatorname{Ir}(\mathrm{COD})_{2}\right] \mathrm{BF}_{4}$, $[\operatorname{Ir}(\mathrm{COD}) \mathrm{Cl}]_{2},\left[\mathrm{Rh}(\mathrm{COD})_{2}\right] \mathrm{BF}_{4},\left[\mathrm{Rh}(\mathrm{COD})_{2}\right] \mathrm{OTf},[\mathrm{Rh}(\mathrm{COD}) \mathrm{Cl}]_{2},(\mathrm{COD}) \mathrm{Ru}(\text { methallyl })_{2}+2 \mathrm{HBr}$, and $(\mathrm{COD}) \mathrm{Ru}$ (methallyl $)_{2}+\mathrm{BF}_{3}+\mathrm{HBF}_{4}$. The last two precursors have been described by Genet and coworkers in refs 6 and 7 of the text and are expected to provide $\mathrm{LRuBr}_{2}$ and $[\mathrm{LRuH}(\mathrm{COT})] \mathrm{BF}_{4}$ respectively. Structures for the 32 phosphine ligands are shown on the last page of this Supporting Information. BICP, (S,R)-Indan-Ambox, and the PennPhos ligands were obtained from Chiral Quest, Inc. (State College, PA). Josiphos type ligands were obtained from Solvias, Inc. All of the remaining ligands were purchased from the Strem Chemical Company.

Screening reactions were conveniently carried out in $1 \mathrm{~mL}$ vials contained in 96 well plates. The vials were charged in a Vacuum Atmospheres drybox using Gilson liquid handlers under an atmosphere of dry nitrogen. Each vial was charged with aliquots of three stock solutions as follows: (1) Chiral phosphines were added in the form of stock solutions (toluene): $30 \mu \mathrm{L}$ of a $10 \mu \mathrm{mol} / \mathrm{mL}$ solution per vial; e.g., $168 \mu \mathrm{g}$ of BINAP per well. (2) Metal precursors were added in the form of stock solutions (ethanol or THF): $30 \mu \mathrm{L}$ of a $9 \mu \mathrm{mol} / \mathrm{mL}$ solution per well. (3) The substrate was added in the form of $300 \mu \mathrm{L}$ of a 90 $\mu \mathrm{mol} / \mathrm{mL}$ solution (ethanol) per well, i.e. $6 \mathrm{mg}$ of substrate per well. The plate was sealed with an air-tight 
cover and removed from the drybox. The system was flushed with hydrogen and then maintained under 65 psi $\mathrm{H}_{2}$ for $12 \mathrm{~h}$ at either room temperature (Rh and Ir precursors) or $40{ }^{\circ} \mathrm{C}$ (Ru precursors). Stirring was maintained using a locally modified commercial vortexing unit. At the conclusion of the run the plate was transferred to an autosampler and the yield and conversion were determined by chiral hplc analysis (Chiralpak AS, $60 \%$ heptane, 39.2\% isopropanol, $0.4 \%$ trifluoroacetic acid, $0.4 \%$ n-hexylamine, $40{ }^{\circ} \mathrm{C}$ ).

\section{Diphosphine and Related Ligands Used in this Study.}
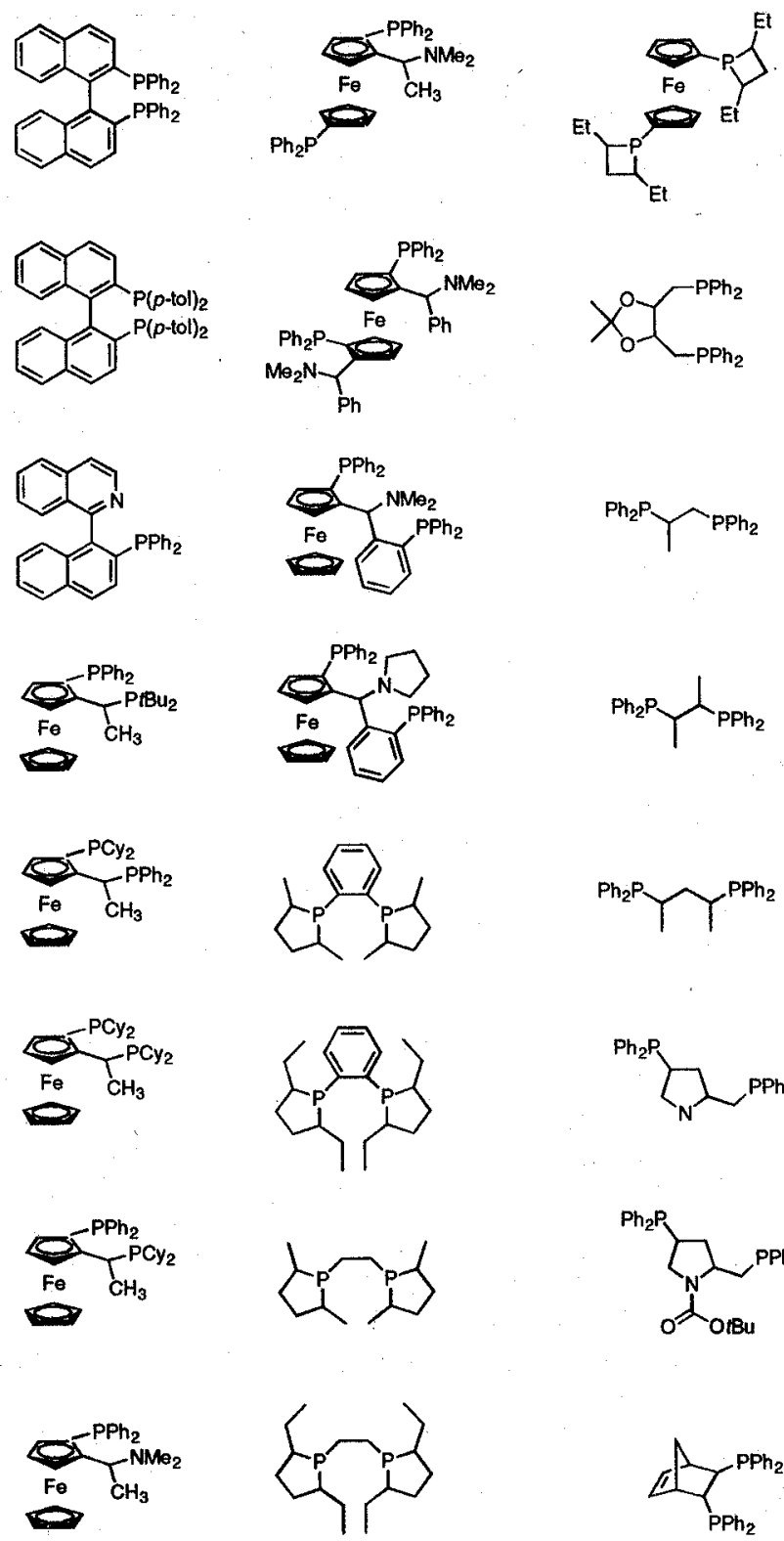
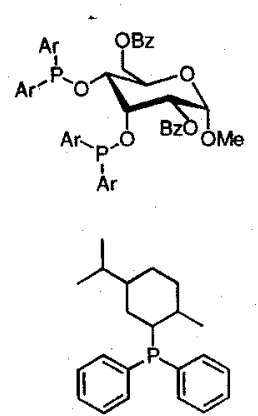<smiles>CC(CPc1ccccc1)Pc1ccccc1</smiles><smiles>CP(c1ccccc1)c1ccccc1P(C)c1ccccc1</smiles><smiles>CC(P)C(C)Pc1ccccc1</smiles><smiles>[R]C1COC(c2ccccc2P)=N1</smiles><smiles>CC(CC(C)Pc1ccccc1)Pc1ccccc1</smiles><smiles>CC1CC2C(C)CC(C1O)P2c1ccccc1P1C2CC(C2C)[C@@H]1C</smiles><smiles>Pc1ccccc1</smiles><smiles>CC(C)C1CC(Pc2ccccc2P2C3CC(C(C)C)C(C(C)C)C2CC3C(C)C)C2CC1C2C(C)C</smiles><smiles>CCOC(=O)N1CC(Pc2ccccc2)CC1Cc1ccccc1</smiles>

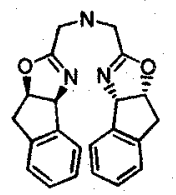<smiles>C1=CC1Pc1ccccc1</smiles> 